\title{
緑地の快適性構造とその地域特性
}

\author{
藤 井 英二 郎*

\section{Structure of Amenity and its Regional Characteristics of Open Spaces} \\ By Eijiro FUJII*
}

\section{1. はじめに}

緑地の快適性がどのような要素によって構成されてい るのかという問題に関連した研究としてはこれまでに森 林美学的研究や戸外空間の視覚的構造解析, 緑量と満足 度との関係に関する研究などが上げられる。

森林美学的研究には大阪営林局 (1933, 1936) や小林 (1935), 小林 (1936) などがあるが, 評価対象は森林に 限られていたし，評価基準が美に限定されていた。

戸外架間の視覚的構造解析に関しては抙口（1975）が これまでの研究成果をモノグラフ化した。

緑量之人間の視覚的満足感との関係は杉並区役所 （1973），町田市環境調查委員会（1973）をはじめとし て，高橋・野田（1975）や浅川（1976），青木（1977） などによって研究され, 緑量の測定方法に差異はあるも のの一定の成果が得られた。

しかし，人間環境のよさを快適性といらならば，森林 美や視覚的空間構造, 緑量などは快適性を構成する要素 ではあっても，それらですべてではない。森林美や緑量 などの緑地構成要素がどのように組み合わさって緑地 (これは人間環境の一要素) であり，これが人間環境の 中でどう位置づけられるのかという問題もある）の快適 性が構成されるのかを明らかにしようとしたのが本研究 である。これに類した研究としては, 品田・立花(1975) を上げることができよう。そこでは植生の人間主体的な

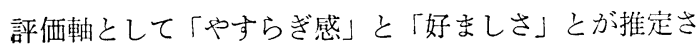
れている。

本研究を進める上で海中公園センター理事長池ノ上容 氏, 一葉大学の沼田真教授, 本多体教授, 国際商科大学 の望月衛教授には貴重な御助言を頂いた。また,アンケ 一ト調査及びその集計に当っては恵泉女学園短大, 日本 道路公団, 野田市役所, 太田区, 品川区, 千葉大学園芸 学部の関係諸氏, 及び千葉大学理学部数学科, 同大ュン ピェーターセンターの関係諸氏に御協力頂いた。これら の方々に厚くお礼申し上げる。

\section{2. 方 法}

緑地の快適性構造把握の方法として緑地を構成する要 素に対する人々の要求度をアンケート調查した。緑地構 成要素に対する要求度は緑地の存在する位置によって変 化することが\}想されたので, 緑地を都市地域緑地, 田 園地域緑地, 自然地域緑地の 3 つ区分した。緑地構成 要素は植生や地形, 気象などの自然的要素や施設などの 人工的要素を中心に 42 項目をとり上げた（表 1 )。また， 緑地構成要素に対する要求度は「非常に不必要」,「かな り不必要」,「やや不必要」,「どちらでも」,「やや必要」, 「かなり必要」，「非常に必要」の7段階の中からひとつ 選んでもらった。調査対象者は表 2 に示した 5 グループ

\section{表 1 緑地の快適性調查項目}

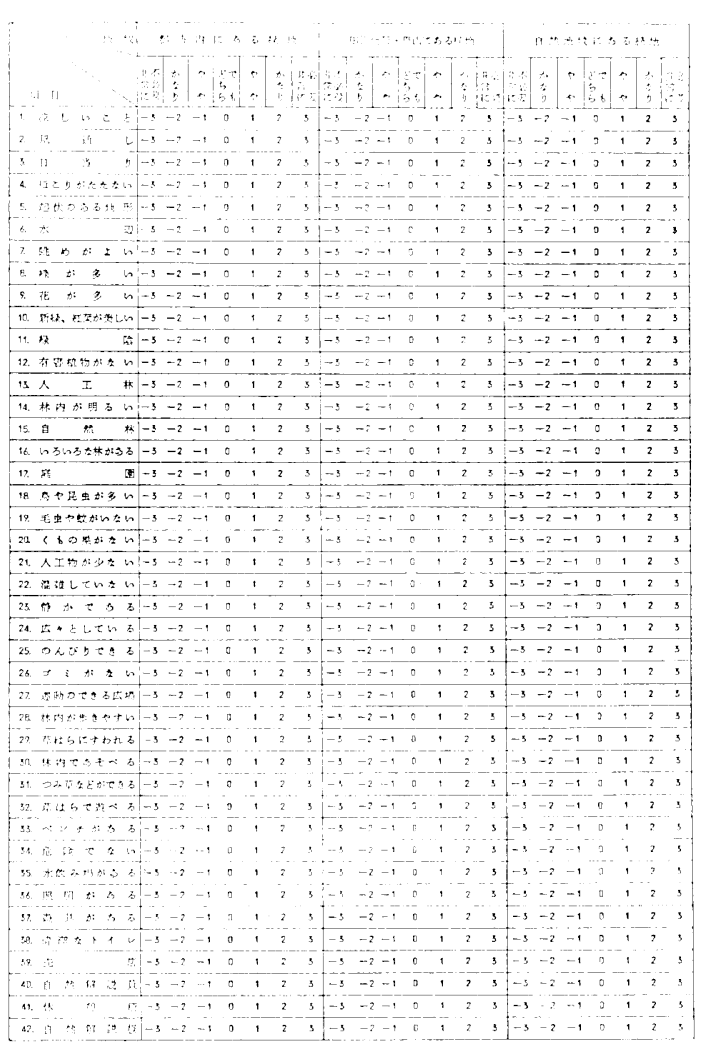

* 筑波大学農林学系 
表 2 アンケート対象者

\begin{tabular}{|c|c|c|c|c|c|c|}
\hline \multirow{2}{*}{$\begin{array}{l}\text { グループ } \\
\text { 蝟泉女学園 } \\
\text { 生 }\end{array}$} & \multirow{2}{*}{\begin{tabular}{|l} 
配布数 \\
100
\end{tabular}} & \multirow{2}{*}{$\begin{array}{c}\text { 回収数 } \\
95 \\
95\end{array}$} & \multicolumn{3}{|c|}{$\begin{array}{c}\text { 有 効 回 答 数 } \\
\text { 都市地田園地自然地 } \\
\text { 域緑地域緑地域緑地 }\end{array}$} & 備 考 \\
\hline & & & 72 & 63 & 63 & 女性のみ \\
\hline 野田市職員 & 200 & 76 & $\begin{array}{c}62 \\
(50)\end{array}$ & $\begin{array}{c}58 \\
(46)\end{array}$ & $\begin{array}{c}53 \\
(46)\end{array}$ & $\begin{array}{l}\text { ()中の } \\
\text { 男性のZ } \\
\text { 分析 }\end{array}$ \\
\hline 千葉大学生 & 107 & 47 & $\begin{array}{c}43 \\
(38)\end{array}$ & $\begin{array}{l}41 \\
(35)\end{array}$ & $\begin{array}{c}42 \\
(35)\end{array}$ & "I \\
\hline 䆃路公団職 & 50 & 23 & $2 \overline{5}$ & 22 & 21 & 男性の文 \\
\hline $\begin{array}{l}\text { 太田，品川 } \\
\text { 区主婦 }\end{array}$ & 50 & 23 & 18 & 21 & 23 & 女性のみ \\
\hline
\end{tabular}

である。恵泉女学園学生は恵泉女学圊短大園芸生活科酒 属し, 年榆は20藏前後である。野田市職員では有効回答 の中で男性のデータのみを分析対象之し，年秢は大半が 20歳〜50歳である。千葉大学生は園芸学部造園学科之環 境緑地学科の 2 年生で, 年秢は20歳前後であり男性のデ 一タのみを解析した。道路公団職員法町田市の日本道路 公団試験場の男性職員で，年秢は 20 歳 40 歳が大半であ る。太田，品川両区の主婦は大半が30歳〜50歳である。 調査期間は1975年 7 月〜 11月である。

データの解析は上述の 5 つのグルーブごとに行なっ た。まず，緑地の快適性構造と乞の地域特性の全般的傾 向を把握するために，42の緑地構成要素ごとに要求度の 平均值を求め, それらを調查対象グルーフ間，及び地域 間（都市地域緑地之田園地域緑地, 自然地域緑地の間） で比較した。次に人々は 420 緑地構成要素の必要度を決 定する祭に，一要素ごとに別個の評価基準をもっている のではなく，いくつかの基準で評価していると考えられ ることから，42の要素間の相関係数をもとに直接バリマ ックス法によって評価基準としての因子を求めた（芝 1972)。また，いくつかの因子軸上に因子負荷量によっ て42の要素を位置づけ，要素のグルーピング亮行なっ た。こうしてある因子に対して因子奂荷量の大きい要素 を因子構成要素とした。さらに，いくつかの因子構成要 素の要求度 (平均値) の平均をとって，峁る因子に対古 る要求度 (因子要求度) とした。そして, 緑地の評価基 準としての因子構成要素，因子要求度によって緑地の快 適性構造とその地域特性を検討した。

\section{3. 結果及び考察}

1）快適性構造及びその地域特性の全般的傾向

調查対象グループごとに42の緑地構成要素汇対する要 求度の平均值を求めると, 調查対象グループ間でかなり 類似した傾向を示すとともに，都市地域緑地に比べて自

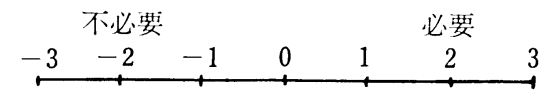

涼しいこと

風通し

日当》

ほこりがたなない

起伏のある地形

水 辺

眺めがよい

緑が多い

花が多い

新緑、紅葉が美しい

緑 陰

有害植物がない

人工林

林内が明るい

自然林

いろいろな林がある

延 国]

鳥や昆虫が多い

毛虫や蚁がいない

くもの巣がない

人工物が少ない

混雉していない

静かである

治々ししてる

のんびウできる

ゴミがない

軏動のできる広埸

林内少抄きや方い

草法に方われる

森内て遊べる

つみ草などができる

草はらで遊べる

ベンチがある

危俟でない

水飲又埸が奇る

照明がある

遊具がある

清潔なトイレ

恣 㕍

自然解説山

休烈所

自然解説板

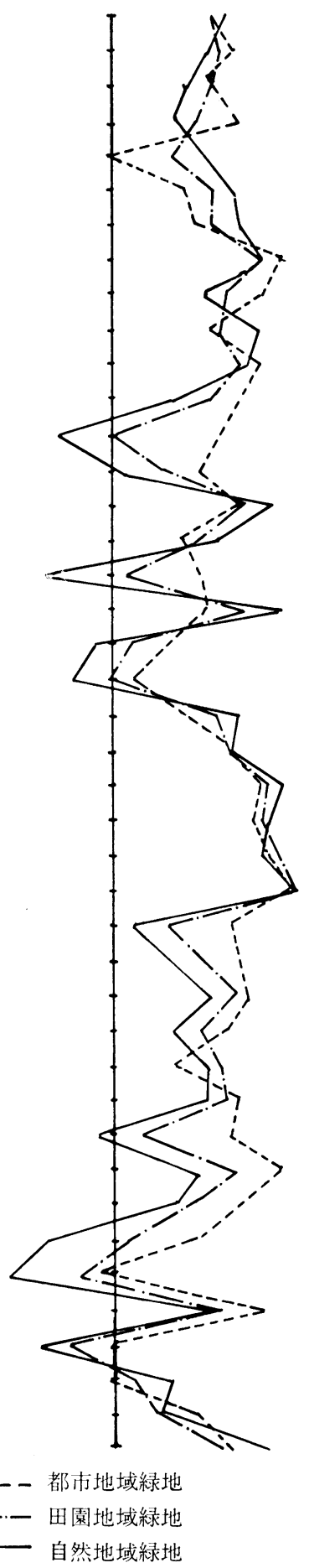

図1 緑地構成要素に対する要求度の地域比較 一恵泉女学園学生における一 

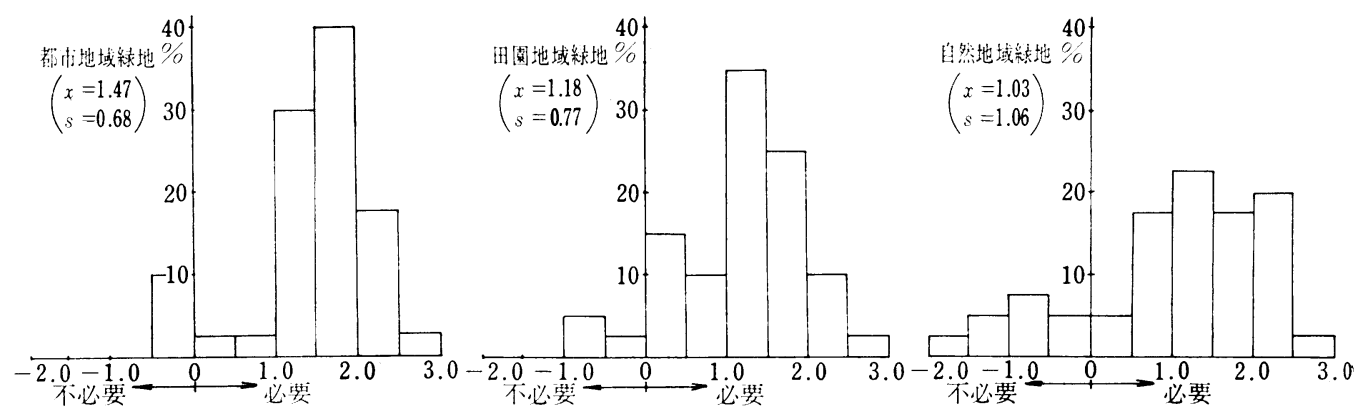

図 2 緑地構成要素に対する要求度度数分布の地域比較一恵泉女学園学生において一

注） $\bar{x}=$ 平均值, $\mathrm{s}=$ 標準偏差

然地域緑地では緑地構成要素に対する要求度が要素によ って差異が著しく，田園地域緑地ではその中間的傾向を 示した。図 1 は恵泉女学園の例である。こうした傾向は 緑地構成要素に対する要求度を10階級に区分し，それぞ れの階級に属する緑地構成要素数の百分率を縦軸にとっ た図2をみるとさらにはっきりと理解できる。すなお ち, 都市地域緑地では42の緑地構成要素に対する要求度 が全般的に高くバラッキが小さい。これに対して自然地 域緑地では要求度の低い要素と高い要素とが混在しバラ ツキが大きい。以上のことから都市地域緑地に拈ける人 々の緑地構成要素に対する要求は「総花」的であり，一 方自然地域緑地に打けるとれは「一点豪華」的であると 言える。そして田園地域緑地はそれらの中間的傾向を示 すようである。

調查対象グループごとに緑地構成要素に対する要求度 を地域比較すると，いくつかの要素において都市地域緑 地から田園地域緑地，自然地域緑地の順に漸増，または 逆に漸減する傾向がみられる。そこで, 都市地域緑地と
自然地域緑地との間に要求度で有意水準 0.05 ( $\mathrm{T}$ 検定) 以上の差がある緑地構成要素（漸增と漸減との 2 タイフ がある）と有意水準0.05で差がみられない要素とに区分

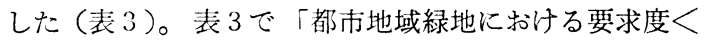
自然地域緑地にお活る要求度」タイプに属する要素群は 自然的要素群で, 逆に「都市地域緑地における要求度〉 自然地域緑地における要求度」タイプに属する要素群は 人工的要素が多い。また，「都市地域緑地に拈ける要求 度二自然地域緑地に晾方要求度」タイプに属する要素 群は, 要求度を考兄合わせると都市地域, 田園地域, 自 然地域の別なく要求度の高い必須要素と逆にどの地域で も要求度の低い不必要要素とであることが理解できる。 例えば，必須要素には「ゴミがない」「涼しいこと」な ぞがあり，不必要要素には「売店」がある。

以上の考察から「総花」的な都市地域緑地とは異な り，「一点豪華」的であった自然地域緑地の「豪華さ」 は自然的要素であったことがわかる。

2）緑地の快適性構成因子

表 3 都市地域緑地と自然地域緑地における緑地構成要素に対する要求度比較

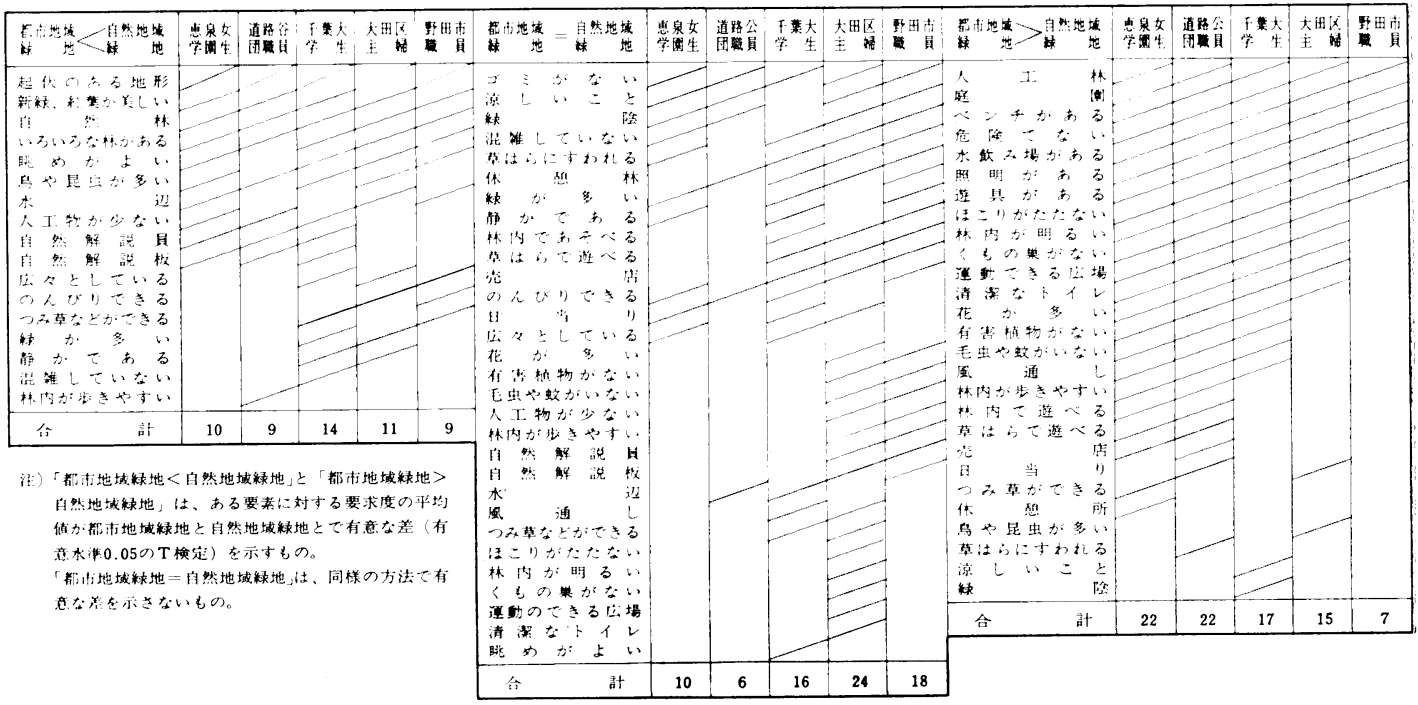


表 4 緑地快適性の因子構造とその地域比較一恵泉女学園学生において一

\begin{tabular}{|c|c|c|c|c|c|c|c|c|c|c|c|c|c|c|c|}
\hline 地城 & & 都 市 & 地 域 & 紻地 & & & 田 固 & 地 城 & 綀地 & & & 自 然 & 地㳦 & 性地 & \\
\hline 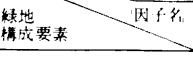 & 休息性 & 人工性 & 自然快性 & 清涼性 & 自然美性 & 休息性 & 人士性 & 自㫮挟性 & 清涼性 & $\begin{array}{l}\text { 鼻然的 } \\
\text { 遊践性 }\end{array}$ & 休息性 & 人工性 & 自然快性 & 清涼性 & 遊战的 \\
\hline 杭 & .43 & .11 & .11 & .41 & .30 & .41 & .19 & .06 & .47 & -.10 & .54 & .17 & .10 & .37 & .04 \\
\hline 鈢 加 多 & .75 & .09 & -.05 & .18 & .04 & .70 & .05 & -.05 & .41 & .06 & .84 & .05 & -.07 & .10 & .08 \\
\hline 花 が多い & .66 & .10 & .10 & .21 & .27 & .42 & .10 & .11 & .60 & .20 & .48 & .37 & .08 & .19 & .12 \\
\hline 㓌 & .57 & .04 & .07 & .45 & -.01 & .36 & .00 & -.09 & .33 & -.01 & .68 & .08 & -.06 & .09 & .18 \\
\hline 鳥や昆虫が多い & .46 & .09 & -.12 & .29 & .30 & .59 & .07 & -.08 & .25 & .05 & .82 & -.11 & -.00 & -.04 & -.04 \\
\hline 混櫵していない & .62 & .13 & .18 & .09 & -.01 & .58 & .19 & -.04 & .11 & .08 & .43 & .12 & -.14 & .10 & -.06 \\
\hline 静かでおる & .91 & -.08 & .03 & .02 & .09 & .94 & -.02 & .08 & -.09 & .03 & .87 & .03 & .01 & -.10 & .01 \\
\hline 広々としている & .93 & .04 & .01 & -.05 & .08 & .89 & .05 & .02 & .01 & -.04 & .79 & .12 & -.03 & .01 & -.07 \\
\hline のんびりできる & .89 & .02 & -.02 & -.03 & .02 & .91 & .06 & -.09 & -.01 & .06 & .70 & .21 & -.14 & -.03 & .30 \\
\hline$コ ミ か ゙ な い$ & .88 & .02 & .07 & .04 & -.12 & .90 & -.00 & -.02 & .04 & -.03 & .83 & .07 & -.00 & .01 & -.06 \\
\hline 運娌のできる広場 & .61 & .26 & -.16 & .04 & .10 & .19 & .34 & .09 & .10 & .10 & .06 & .70 & -.08 & .01 & -.12 \\
\hline 枧內が生きや十い & .44 & .24 & .07 & .04 & .18 & .33 & .52 & .11 & .18 & .14 & .12 & .60 & -.04 & .19 & -.01 \\
\hline 草にらにすかれる & .78 & .05 & .06 & .14 & .11 & .57 & .07 & .13 & .14 & .40 & .33 & .58 & .02 & .05 & .60 \\
\hline 草はらで遊へる & .53 & .23 & -.11 & .09 & .06 & .31 & .21 & -.05 & .03 & .85 & .27 & .48 & -.06 & .01 & .75 \\
\hline 危険でない & .63 & .42 & .04 & -.07 & -.04 & .35 & .46 & .14 & -.08 & .33 & .20 & .54 & .07 & .05 & .29 \\
\hline 清䍘なトイし & .67 & .41 & -.00 & -.10 & -.04 & .45 & .73 & -.04 & .09 & -.07 & .35 & .61 & -.11 & .14 & -.10 \\
\hline 林内が明るい & .24 & .58 & .04 & .12 & .14 & .23 & .61 & .20 & .27 & .10 & .15 & .76 & .03 & .15 & -.07 \\
\hline 沽 & .25 & .51 & .05 & .06 & .03 & -.06 & .46 & .14 & .09 & -.01 & -.19 & .60 & .00 & .06 & -.01 \\
\hline 毛虫や蚊がいない & .15 & .34 & .86 & .11 & .00 & .01 & .43 & .81 & .05 & -.16 & -.04 & .41 & .79 & .05 & -.23 \\
\hline くしの粿がない & .09 & .42 & .79 & .09 & -.00 & -.04 & .39 & .85 & .11 & -.13 & -.14 & .44 & .79 & .15 & -.11 \\
\hline ヘンチがる & .13 & .68 & -.03 & -.05 & -.02 & .02 & .82 & -.03 & -.13 & .13 & -.11 & .86 & .02 & .02 & .03 \\
\hline 水的文場加市る & .40 & .69 & -.08 & -.12 & -.01 & .16 & .86 & -.05 & .01 & .01 & .14 & .75 & -.11 & .07 & -.14 \\
\hline 照 明が市る & .28 & .76 & -.02 & -.13 & -.15 & .08 & .68 & .02 & -.12 & -.13 & -.05 & .85 & -.02 & -.14 & -.07 \\
\hline 避具が苛光 & -.06 & .83 & -.03 & .06 & .14 & -.19 & .64 & .13 & -.00 & .04 & -.33 & .48 & .16 & .04 & .11 \\
\hline 売 & -.00 & .81 & .12 & .20 & .02 & -.14 & .62 & .25 & .12 & .02 & -.10 & .69 & .18 & -.07 & .09 \\
\hline 盽 & .17 & .68 & -.09 & .01 & .07 & .03 & .83 & -.08 & .11 & -.00 & -.03 & .47 & -.05 & .17 & -.08 \\
\hline 涼 $し \backsim=$ : & .33 & .00 & .05 & .80 & .01 & .34 & .15 & .11 & .76 & -.07 & .57 & .11 & .00 & .37 & .09 \\
\hline 通 & .41 & .01 & -.05 & .84 & -.04 & .28 & .22 & -.09 & .86 & .02 & .46 & .18 & -.06 & .69 & .13 \\
\hline 当 & .34 & -.02 & -.02 & .42 & .12 & .30 & .08 & -.04 & .84 & -.03 & .33 & .03 & .02 & $.91\rfloor$ & .02 \\
\hline 起伏のある地形 & -.03 & -.12 & .02 & .24 & .32 & .19 & .07 & -.22 & .22 & -.15 & .34 & -.07 & -.09 & .35 & -.12 \\
\hline 眺 めが & .32 & .22 & .06 & .35 & .72 & .41 & .14 & .06 & .57 & -.02 & .63 & .22 & .03 & .16 & .10 \\
\hline 新制・紅菒が英！い & .44 & .15 & -.05 & .10 & .83 & .47 & -.01 & .01 & .45 & .11 & .73 & .02 & .02 & .10 & .06 \\
\hline 然 情 & .23 & -.13 & .06 & .14 & .49 & .47 & -.11 & -.03 & .29 & -.06 & .82 & -.14 & .04 & .03 & -.00 \\
\hline いろいるな林がる & .27 & .11 & -.05 & .04 & .43 & .30 & -.01 & .02 & .21 & .09 & .61 & .07 & .10 & -.16 & .02 \\
\hline 人工物が少ない & .22 & -.28 & .36 & -.03 & .10 & .36 & -.08 & .01 & .04 & -.09 & .42 & .10 & -.09 & -.12 & -.15 \\
\hline I & .17 & .29 & .06 & .26 & .03 & .02 & .32 & .03 & .11 & -.10 & .12 & .15 & .02 & -.02 & -.19 \\
\hline 自 然 解 哾 目 & .14 & .17 & -.01 & .11 & .22 & .02 & .48 & -.11 & .21 & -.11 & .05 & .20 & .01 & .09 & -.03 \\
\hline 自 然 解 说 板 & .27 & .22 & .06 & -.01 & .19 & .28 & .53 & -.31 & .16 & -.05 & .45 & .22 & -.25 & .18 & -.23 \\
\hline ほこりがたたない & .47 & .28 & .27 & .34 & -.13 & .42 & .01 & .21 & .48 & .07 & .32 & .23 & .15 & .28 & .09 \\
\hline 有害槙物かない & .23 & .12 & .14 & .12 & -.01 & .16 & -.02 & .27 & .02 & .32 & .21 & .31 & .29 & -.09 & .26 \\
\hline 林内で遊てる & .27 & .16 & .01 & .18 & .19 & .31 & .05 & .00 & .11 & .72 & .19 & .49 & .07 & -.04 & .76 \\
\hline つふ草などができる & .39 & .23 & -.04 & .03 & .30 & .31 & .17 & .03 & -.01 & .70 & .38 & .39 & -.03 & .04 & .67 \\
\hline 因子 寄 与 & 9.59 & 5.46 & 1.78 & 2.67 & 2.40 & 7.40 & 6.32 & 1.93 & 4.23 & 2.39 & 9.16 & 7.38 & 1.62 & 2.11 & 2.58 \\
\hline
\end{tabular}

上述の結果からもわかるように人々は42の緑地構成要 素に対して個々別々の尺度で要求度を決定しているので はなく，いくつかの尺度でもって要求度を決定している と考えられる。こうした評価尺度を抽出するために 42 の 緑地構成要素間の相関係数をもとに直接バリマックス法 によって評価尺度としての因子を推定した。 5 グループ で推定された因子名及びその内容は以下のようである。 また，表 4 に恵泉女学園の因子構造を一例として上げ た。

休息性：この因子は 5 つの調查対象グループ，3つの 地域緑地のいずれでもみいだされるもので，この因子を 構成する因子負荷量の䯩い要素（因子構成要素と呼ぶ） はグループや地域によって異なるが，それらに共通して 含まれる基本的要素がある。それは「のんびりできる」，

「広々としている」，「静かである」などの要素で，これ らは人々の休息にとって基本的条件であり，これらに加 えてグループや地域に特異的な休息的条件が含まれるも のと考えられる。

清涼性：緑地の気象的要素を評価する因子と考兄ら
れ，因子構成要素はそれほど多くない。グループや地域 の別を問わない基本的因子構成要素には「涼しいこ之」, 「風通し」，「日当り」などがある。この因子が双いださ れないグループや地域では上述の要素が休息性の因子構 成要素となっている。

自然快性：この因子の構成要素は数が少ないため因子 名の推定が困難であったが，「毛虫や蚊がいない」，「く もの栄がない」という基本的な因子構成要素から, 自然 の中の不快さが除去された状態を示す因子として自然快 性と命名した。この因子の構成要素はグループや地域に よる差が少ない。また，この因子が多いだし得なかった グループでは上述の因子構成要素が，都市厌び田園地域 緑地では後述する管理性因子の構成要素となり，自然地 域緑地では人工性の構成要素となっている。

自然的遊戯性：人工的施設によらず自然の中で遊ぶこ とを指しており，基本的な因子構成要素は「草はらで遊 べる」，「林内で遊べる」などである。この因子がみいだ されないグループや地域では休息性や管理性の構成要素 となることが多い。 
清潔性 : この因子は野田市職員と千葉大学生との田園 地域緑地に打いてのみ推定され, その他のグルーブ, 地 域では休息性に含まれることが多い。この因子の基本的 構成要素は「ゴミがない.|である。

人工性：この因子はグループ，地域を問わずかなり一 般的にみいだされるが，その構成要素は都市地域ふら田 園地域, 自然地域緑地の順に数が增加する傾向がみられ る。すなわち, 都市地域緑地では「遊具がある」や「売 店」,「休媳所」が主要な構成要素であるが, 田園地域緑 地や自然地域緑地では「林内が歩きやすい」や「林内が 明るい」というような人為的に管理された自然を示す要 素まで人工性因子の構成要素之なっている。このことは 人工性の判断基準が都市地域緑地よりも田園地域及び自 然地域の緑地においてより戦しくなると考えてょい。一 方, 「水飲又場がある」や「照明がある」，「清潔なトイ レ」などの要素は都市地域緑地では休息性や後述する便 益性, 管理性などの構成要素となり, 自然地域緑地では 人工性の構成要素となることが多い。以上のことから， 人間が作った施設であっても人工性として認識されず に，休息性や便益性，管理性として認識されるものがあ ることがわかる。そして，人工性の認識は周囲の状況に よって変化する相対的なるので㐫り，したがって，都市 地域から田園地域, 自然地域へと周囲の自然性が高まる につれて，人工性に含まれる緑地構成要素が増加する。

便益性 : 太田, 品川区主婦で都市地域緑地にだけみい だされた因子であり，構成要素は「水飲及場がある」，

「清潔なトイレ」、「照明がある」である。上述のように これらの要素は他のグループの都市地域緑地評価では休 息性や管理性の要素とされている。

管理性：千葉大学生と道路公団職員とでみいだされた 因子で, 上述した便益性や自然的遊鍆性, 自然快性など を構成していた要素が混然として包括されている。この ことから緑地管理者がなすべきこととして評価されてい るものと考えられる。これは調査対象とした千葉大学生 が造園学科之環境緑地学科とに属し, また道路公団職員 も緑地管理の問題に接する機会が多いと考えられること から，緑地管理者的な評価を下した之思われる。

自然性: 道路公団職員之太田, 品川区主婦とでみいだ される因子で, 基本的構成要素は「自然林」「鳥や昆虫 が多い」「いろいろな林が脑る」などである。他のグル 一プや地域ではこれらの要素は休息性や後述する自然美 性の構成要素となることが多い。

自然美性 : 恵泉女学園生と野田市職員との都市地域緑 地でみいだされた因子で, 基本的構成要素は「眺めがよ いよ「新緑, 紶葉が美しいてである。これらは他のグ ループや地域では休息性の構成要素となる場合が多い。

静寂性 : 道路公団職員の都市地域緑地評価でのみ推定 された因子で,「静かである」と「混雑していない」,
「広々としている」が因子構成要素であるが，他のグル 一プや地域では休息性汇含ま机る要素である。

以上，今回11個の因子が推定されたわけであるが，い ずれのグループ，いずれの地域においても累積因子寄与 率は25\%以下と低い。これは緑地の構成要素として42む の項目を選んだことによるものと考えられる。この点に 関して今後さらに方法を变えて調査, 娭討を加えたい。

3）快適性搆成因子及び因子構成要素の地域比較

表 4 の恵泉女学園の因子構造をみると, 自然快性と清 涼性は 3 地域緑地とも注汴同じ要素で構成されており, 地域による差が少ない。これ対して休息性と人工性で は地域によって構成要素にかなりの差がみられる。都市 地域緑地の休息性は前述した休息性の基本的構成要素に 自然的遊歔性要素が加わり, 自然美性が独立して認識さ れているのに対して, 田園地域と自然地域の緑地の休息 性では休息性の基本要素に自然美性要素が加わり, 自然 的遊戲性が独立して認識されている。一方, 人工性では ベンチや水飲み場, 照明, 売店, 遊具（都市地域緑地の 人工性要素)に加えて, 田園地域及び自然地域緑地では自 然的遊戯性要素まで人工性要素として認識されている。

以上の上うに快適性满成因子及び因了構成要素の地域 比較を他の 4 グルーフについても行なった結果, 因子構 成要素の包提関係から, 緑地快適性の評価尺度として推 定された11因子の中でも，休息性と人工性，清涼性の 3 因子が人々の緑地快適性評価の基本之考兄られる。すな わち, 緑地の快適性を評価吉る場合の基本的尺度は気象 的条件が整い(清涼性)，地域泪応した休息が得られ るか（休息性），てして人工的要素があるか（人工性） である。そしてこれら 3 因子はグループや地域の別を問 わずかなり普遍的に推定されるものであった。その他の 諸因子の構成要素は上述の 3 因子，とくに休息性と人工 性の要素となることが多く, 特定のグループや地域に独 自のものであると考光られる。例光ば，自然美性因子は 都市地域緑地の久で推定され，管埋性因子は千集大学生 と道路公団職員だけで推定された。

休息性と人工性の構成要素の地域変動をみると, 休息 性では次の 2 タイプに区分できる。ひとつは恵泉女学園 生や野田市職員, 道路公団職員にみられる傾向で,「の んびりできる」や「広々としている」、「静かである」な どの休息性の基本的構成要素に地域に特異な要素, 例え ば都市地域緑地では水飲又場やトイレ，照明などの便益 性要素が加わり，自然地域緑地では「眺めがよい」や 「新緑・紅葉が美しい」などの自然美性要素が加わって 休息性を構成しているタイブである。もらひとつは千葉 大学生之太田・品川区主婦にみられたもので, 都市地域 緑地では休息性の基本的構成要素に自然美性要素などの 自然的緑地構成要素が加わり, 自然地域緑地では基本的 構成要素以外の付加的要素が休息性から分離し（千葉大 
学生では新たな因子が独立して推定できず，太田・品川 区主婦では自然性因子として独立した)，基本的構成要 素の又で休息性が形成されているタイプである。はじめ のタイプは地域独自の休息性，例总ば都市地域的休息性 や白然地域的休息性を意識しているのに対して，市との タイフは, 都市地域緑地に拀いて自然美性と休息性とが 一緒になって，すなわち自然地域的休息性が意識されて いることから，都市地域緑地では望又得ないものとして 一括されているのであ万らか。この点については，休息 性認識汇対する 2 つタイブとグループの特性との関倸 の検討をも含めて，機会を改めて検討を加光たい。

人工性では各グルーブともにか就り類似した傾向を示 している(但し，千葉大学生では人工性因子が推定でき ず,類似した因子として管理性が推定されている)。都市 地域緑地では庭園や遊具, 売店などが人工性因子を構成 しているが，田園地域緑地から自然地域緑地になると便 益性要素や自然的遊戯性要素(「林内で遊べる」や「草汸ら で遊べる)など」までが人工性因子の中含恋れてくる。

4）因子要求度とその地域比較

因子構成要素の要求度の平斯值因子要求度として, グループや地域の別を問らことなくかなり普遍的にみら 礼万休息性，人工性，清涼性の因子要求度を求好々表 5〜7の上5江なった。休息性因子要求度涊忠泉父学園 学生で注各地域之も類似した要求度を示しているのに対 して, 千葉大学生や太田・品川、主婦で法都市地域から 四園地域, 自然地域の順に要求度が增加与る倾问がみら れる。このことは前述の休息性構成要素の地域変動に拐 いて, 千葉大学生と太田・品川区主婦は都市地域緑地で は休息性は望み得ないものと認識しているのではないか としたが，その考察と一致するるのである。しかし，千 葉大学生之太田・品川区主婦では都市地域緑地に和汸る 休息性の要求度が低いとはい光, 表 6 の人工性因子要求 度と比較すれば，かなり要求度の高い因子で制るとい兄 る。また，先汇述べた休息性の基本的構成要素はグルー プや地域の別を問わず高い要求度をもつことから，1）

で述べた緑地の必須要素であると考光られる。

人工性因子要求度は全般に標準偏差が大きく，はっき りとした傾向をいらことはできないが，表 3 で都市地域

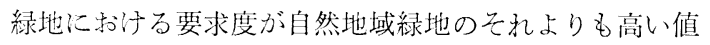
を示い要素に人工的要素が多いことをも考光合わせる と, 人工性因子汶対する要求度は都市地域緑地では比較 的高く，自然地域緑地では低いと言ってょいであろう (表 6 )。

清涼性因子要求度の地域比較では各グルーブに共通す る傾向はみられなかった。要求度は休息性と人工性の中 間的値をとっている(表 7 )。

\section{4. おわりに}

この研究はすでに述べたように緑地の快適性がどうい
表 5 休息性因子要求度の地域比較

\begin{tabular}{|c|c|c|c|}
\hline グルーブ 地域 & 都市地地 & 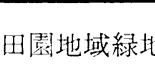 & 地 \\
\hline $\begin{array}{l}\text { 恵泉女学園学 } \\
\text { 生 }\end{array}$ & $\begin{array}{l}2.19 \\
(0.21, \quad 8)\end{array}$ & $\left.\begin{array}{ll} & 2.26 \\
(0.17, & 5\end{array}\right)$ & $\begin{array}{l}2.22 \\
(0.19, \quad 9)\end{array}$ \\
\hline 野四市職員 & $\begin{array}{c}1.71 \\
(0.22,6)\end{array}$ & $\begin{array}{cc}1.79 \\
(0.19, & 5)\end{array}$ & $\begin{array}{ll}2.12 & \\
(0.15, & 3)\end{array}$ \\
\hline 千葉大学生 & $\begin{array}{c}1.42 \\
(0.59,7)\end{array}$ & $\left(0^{2.29}, 1\right)$ & $\begin{array}{ll} & 2.47 \\
(0.16, & 4)\end{array}$ \\
\hline 道路公団職員 & $\begin{array}{l}2.28 \\
(0.13, \quad 6)\end{array}$ & $\begin{array}{c}1.75 \\
(0.26, \quad 9)\end{array}$ & $\begin{array}{c}1.79 \\
(0.56,19)\end{array}$ \\
\hline $\begin{array}{l}\text { 太田, 品川区 } \\
\text { 主婦 }\end{array}$ & $\begin{array}{c}1.75 \\
(0.34,18)\end{array}$ & $\begin{array}{c}2.09 \\
(0.2 \overline{5}, 12)\end{array}$ & $\begin{array}{c}2.78 \\
(0.06, \quad 3)\end{array}$ \\
\hline
\end{tabular}

注）（）の数值沈（標準偏差，因子構成要素数）で ある。因子要求度心最低值 -3.00 (非常に不必 要) と最高值 3.00 (非常に必要) の間他市り, 0.00は「どちらともいえな」ことを示吉。

\section{表 6 人工性因子要求度の地域比較}

\begin{tabular}{|c|c|c|c|}
\hline $\begin{array}{l}\text { 地域 } \\
\text { グループ }\end{array}$ & 都市地域緑 & 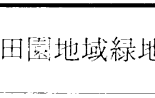 & 当 \\
\hline $\begin{array}{l}\text { 恵泉父学園学 } \\
\text { 生 }\end{array}$ & $(0.86, \quad 6)$ & $(0.77, \quad 5)$ & $\begin{array}{c}-0.20 \\
(0.76, \quad 6)\end{array}$ \\
\hline 野田市職員 & $\begin{array}{c}0.54 \\
(0.90, \quad 5)\end{array}$ & $\begin{array}{c}0.66 \\
(0.50, \quad 5)\end{array}$ & $\begin{array}{c}0.14 \\
(0.61, \quad 7)\end{array}$ \\
\hline （千葉大学生） & $\begin{array}{c}1.71 \\
(0.49,13)\end{array}$ & $\begin{array}{c}1.42 \\
(0.44, \quad 6)\end{array}$ & $\begin{array}{c}-0.14 \\
(0.86, \quad 4)\end{array}$ \\
\hline 道路公四職員 & - & $\left(0^{-0.23}, 1\right)$ & $\begin{array}{c}-0.14 \\
(0.82, \quad 8)\end{array}$ \\
\hline $\begin{array}{l}\text { 太田・品川区 } \\
\text { 主婦 }\end{array}$ & $\begin{array}{c}0.29 \\
(0.47, \quad 2)\end{array}$ & $\begin{array}{c}0.19 \\
(0.35, \quad 3)\end{array}$ & $\begin{array}{l}0.27 \\
(1.15,11)\end{array}$ \\
\hline
\end{tabular}

注）表中の数値:は表 5 之同じ。但し，千葉大学生で は人工性が推定できながたので，管理性因子 要求度を示した。

\section{表 7 清涼性因子要求度の地域比較}

\begin{tabular}{|c|c|c|c|}
\hline 地 & 防市地 & & \\
\hline 生 & $\begin{array}{c}1.66 \\
(0.18, \quad 2)\end{array}$ & $\begin{array}{cc} & 1.41 \\
(0.07, & 3)\end{array}$ & $42)$ \\
\hline 職 員 & $\left(0^{1.56}, 1\right)$ & $\begin{array}{c}1.59 \\
(0.22, \quad 3)\end{array}$ & $\begin{array}{l}46 \\
, \quad 5)\end{array}$ \\
\hline 栥工工 & $\begin{array}{c}0.68 \\
(1.41, \quad 2)\end{array}$ & $\left(\begin{array}{ll}1.46 \\
0.28, \quad 2)\end{array}\right.$ & $\begin{array}{ll} & 1.49 \\
(0.54, & 4)\end{array}$ \\
\hline 職員 & $\left(0^{1.72}, 1\right)$ & - & $\begin{array}{c}1.31 \\
(0.03, \quad 2)\end{array}$ \\
\hline 思・ & & $\begin{array}{c}1.57 \\
(0.11, \quad 3)\end{array}$ & $\begin{array}{c}2.03 \\
(0.06, \quad 3\end{array}$ \\
\hline
\end{tabular}

注）表中の数值况表 5 と同じ。 
うものかを解析しよらとしたものであり，そのために従 来のものとは幾分異なった調查方法をとった。したがっ て, 調査, 解析を進めるに際して不備な点が目についた。 今後さらに調查, 検討を加えて不備な点を補いたい。

\section{引用 文 献}

1）大阪営林局, 嵐山風致林施業計画, 1933

2）……東山国有林風致計画，1936

3）小林義秀, 植生上より観たる風致の維持並に改善, 造園雑誌，2(1)，35-51，1935

4）小林艦一，奥日光小田代区域の「みずなら林」に於 ける風致的考察，造園雑誌，3(1)，8-19，1936

5）嘴口忠彦，景観の構造ーランドスケープとしての日 本の空間一，技報堂，1975

6）杉並区役所，杉並区緑化基本調査報告，1973

7）町田市環境調査委員会, 町田市環境調 査報 告 書, 1973

8）高橋理喜男・野田敏秀，都市環境における快適性の 指標としての緑の量的質的基準化に関与る研究, 造 園雑誌，39(1)，10-19, 1975

9）浅川昭一郎，札幌市における住民の緑地意識につい て (II) 一緑地満足度亡緑地指標之の関係一, 造園雑 誌, $40(1), 18-28,1976$

10）青木陽二, 都市居住者の意識を用いた緑量水準評価 に関する研究，東工大学位・学士論文梗概集， N 0.8 , $130-139,1977$

11）品田銥・立花值美, 都市生態系の視環境評価につい て(1)一未もに植生を対象として一, 沼田真編「都市 生態系の構造と動態に関する研究 (1975)」, 1975

12）芝祐順，因子分析法，東大出版会，1972

(昭和53年 9 月 1 日 受理)

\section{Summary}

The purpose of this study is to clarify the struc. ture of amenity (components of amenity and their integrated forms) of open spaces and its regional differences among urban open spaces, country open spaces and natural area's open spaces. For the persuit of this study it is impotant to analyze people's idea of the best condition of open spaces, so 42 items were selected as the components of open space and the degrees of people's desire for each of them were measured in 7 ranks (from quite unnecessary to very necessary). The questionnairing were held to 5 different groups of people. Results were the following.

1. The degrees of desire for the components of urban open spaces were high in every 5 groups, on the contrary the degrees of desire for the each components of natural area's open spaces varied more widely than those of urban open spaces.

2. Comparing the degrees of desire for a component between urban open spaces and natural area's open spaces, the components of [urban open spaces $>$ natural area's open spaces] type were artificial and those of [urban open spaces $<$ natural area's open spaces] type were natural, and those of [urban open spaces $\div$ natural area's open spaces $]$ type were indispensable or unnecessary for every open space.

3. Through the factor analysis by the Direct Varimax Method based on correlation coefficients between each desire for the components of open spaces, 11 factors were estimated, such as restfulness, artificiality, coolness, natural beauty, natural play, comfortness of nature, cleanliness, utility, management, quietness and naturalness. Among these factors, restfulness, artificiality and coolness were estimated in every groups and regions (urban, country and natural area).

4. Difining the "components of factor" as the components of open spaces which have greater factor loadings, eight factors without restfulness, artificiality and coolness sometimes belonged to the components of these three factors. Therefore eight factors except these three factors were peculiar to a group or to a region. Then restfulness, artificiality and coolness were considered as the fundamental factors or criterions in the case of the evaluation of open spaces.

5. The number of the components of artificiality were inclined to increase from urban open spaces to country and natural area's open spaces, i. e. in urban open spaces japanese garden, children play facilities and stands in open spaces were the main components of the artificiality and in country and natural area's open spaces even the components of utility and natural play belonged to the components of artificiality.

6. Defining the "need of factor" as the mean value of the degrees of desire for the components of a factor, the need of restfulness were the highest, then the needs of coolness and artificiality followed it. Comparing these needs of factors among urban country and natural area's open spaces, the need of artificiality was inclined to decrease in the order of urban, country and natural area. 